\title{
A Review of "Digital Media: Technological and Social Challenges of the Interactive World"
}

Margaret Heller

Loyola University Chicago, mheller1@luc.edu

Follow this and additional works at: https://ecommons.luc.edu/lib_facpubs

Part of the Library and Information Science Commons

\section{Author Manuscript}

This is a pre-publication author manuscript of the final, published article.

\section{Recommended Citation}

Heller, Margaret. A Review of "Digital Media: Technological and Social Challenges of the Interactive World". Journal of Electronic Resources Librarianship, , : , 2012. Retrieved from Loyola eCommons, University Libraries: Faculty Publications and Other Works, http://dx.doi.org/10.1080/

1941126X.2012.706156

This Book Review is brought to you for free and open access by the Faculty Publications and Other Works by Department at Loyola eCommons. It has been accepted for inclusion in University Libraries: Faculty Publications and Other Works by an authorized administrator of Loyola eCommons. For more information, please contact ecommons@luc.edu.

\section{cc) (i) $\ominus$}

This work is licensed under a Creative Commons Attribution-Noncommercial-No Derivative Works 3.0 License. Copyright 2012 Taylor \& Francis 
This is an Author's Original Manuscript of an article whose final and definitive form, the Version of Record, has been published in the Journal of Electronic Resources Librarianship 17 Sep 2012 [copyright Taylor \& Francis], available online at:

http://www.tandfonline.com/10.1080/1941126X.2012.706156

Megan A. Winget and William Aspray, Eds. 2011. Digital Media: Technological and Social Challenges of the Interactive World. Lanham, MD: Scarecrow Press, 237 pp. ISBN: 978-0810881969. List price $\$ 55.00$.

The scholarship of digital media crosses the fields of information science, media studies, the humanities, and technology. This particular volume was the result of a consciously and carefully curated effort to bring those disciplines and perspectives together. Based on the extensively revised papers presented at a 2009 invitation-only workshop, the essays in this book consider four different aspects of digital media through the lens of the author's discipline. While each essay stands individually, the book converges to give a whole view of the scholarship of digital media.

The first section considers why and in what manner to preserve digital media and virtual worlds, considering both professional and amateur efforts in the fan and gaming worlds. One of the essential questions is "Are virtual worlds history?" to which the answer is yes, though given our current ability to preserve these worlds, it seems unlikely they will be extant in their original forms.

Building on that base, the second section of the book examines how the metadata for digital objects is constructed. Particularly interesting in this section is the piece by Catherine C. Marshall, who examines how the concept of the "archival" copy changes for the user based on contexts that neither user nor researcher could predict in advance. Then, the third section of the book shifts markedly with a look at scholarship in the digital humanities, particularly with reference to the scholarly persona and work of Henry Jenkins. 
The fourth and final section of the book examines the role of the digital in creating new culture, with a wonderful essay on composing music digitally by Bruce Pennycook and a fine essay on creating innovation in the academy by Anne Balsalmo.

The rigorous scholarship combined with multiple perspectives make this book a useful addition to the study of digital information and new media. While the specific projects mentioned are several years old at this point, libraries and the scholarly community continue to face the same challenges they address. The essays do not shy away from controversial or potentially unpopular positions, but the book, as a whole, remains balanced.

The theoretical backdrop to newly emerging types of digital media is necessary to understanding why and how libraries might approach collecting, preserving, and disseminating such media objects. Additionally, questions of the place and value of new forms of scholarship and creativity raised in this book are important and yet to be resolved. The overall approach is interdisciplinary by nature and so will be relevant to librarians working in several different areas and to a variety of university programs. 